\title{
The Reaction of 1-[o-Bromomethylphenyl]alkylidenemalonate, Cyanoacetate or Malononitrile with Azide Ion. Intramolecular
} 1,3-Dipolar Cycloaddition

\author{
PER KOLSAKER, PETER O. ELLINGSEN and GRETE WøIEN
}

Department of Chemistry, University of Oslo, Blindern, Oslo 3, Norway

Evidence for intramolecular 1,3-dipolar cycloaddition is presented for the reaction of the title compounds with azide ion. The products are substituted isoindolino $[2,1-c] \Delta^{2}$-triazolines (3) which vary greatly in thermal stability depending on the substituents in the 1- and 9b-positions. Thus, 1,1-dimethoxycarbonylisoindolino $[2,1-c] \Delta^{2}$-triazoline $(3 a)$ is very stable, while the corresponding dicyano compound (3c) decomposes at $-40^{\circ} \mathrm{C}$ to isoindolylidene. malonitrile $(5 c)$. Introduction of a methyl group in 9b-position of triazolines 3 leads to an increase in thermal stability and also to other decomposition products, viz. the hitherto unknown cyanomethoxycarbonyl- $(6 d)$ or dicyano-1-methyl-3H-isoindolenium methylide (6e). Mechanistic proposals are given for the formation of 5 and 6 , involving a primary carbon-nitrogen bond cleavage of the $\Delta^{1}$ triazolines 3 .

Reactions of o-bromomethylbenzylidenemalonates with certain nucleophiles (methoxide or cyanide ion) yielded indans, while others gave the normal benzylic substitution products. ${ }^{1}$ Azide ion, however, reacts with the substrates in a more complex manner and evidence for intramolecular 1,3-dipolar cycloaddition constituting part of the reaction sequence is presented in this paper.

Substrates having both a 1,3-dipolar and a dipolarophilic function suitably spaced within the molecule may undergo intramolecular 1,3-dipolar cycloaddition to form annelated heterocyclic compounds. ${ }^{2}$ When the 1,3-dipole is an azide function, the isolated products may contain all three nitrogen atoms, ${ }^{3}$ or such compounds can be detected as intermediates by spectroscopic means.4

Acta Chem. Scand. B 32 (1978) No. 9
When 0 -bromomethylbenzylidenemalonate $1 a$ was treated with sodium azide in aqueous methanol a compound with all three nitrogen atoms intact was obtained. The absence of azide and $\mathrm{C}=\mathrm{C}$ absorptions in the IR spectrum indicated that an intramolecular cycloaddition had taken place, and the compound was named 1,1-dimethoxycarbonylisoindolino[2,1-c] $\Delta^{2}$-triazoline $(3 a)$. On the other hand, similar treatment of $1 b$ and 1c yielded isoindolylidenecyanoacetate ( $5 b)$ and -malononitrile (5c), respectively. Reaction of $1 b$ with tetrabutylammonium azide at low temperature gave $3 b$ after careful

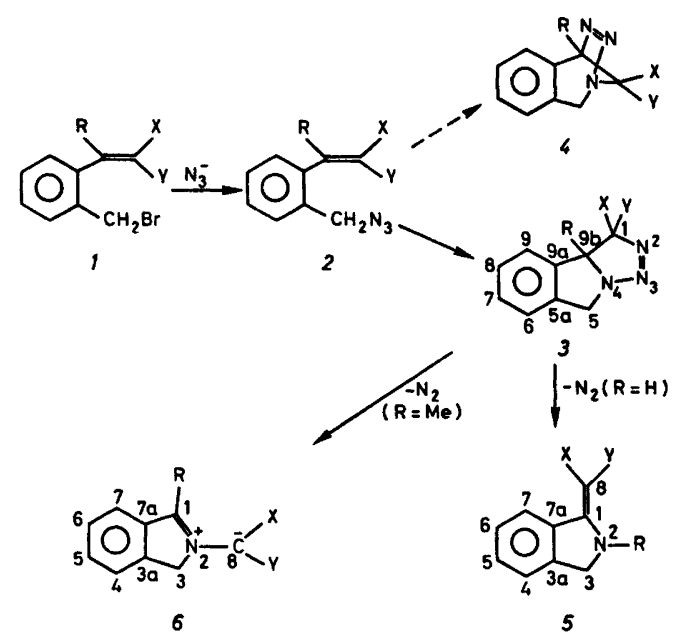

Scheme 1. $a: \mathrm{R}=\mathrm{H}, \mathrm{X}=\mathrm{Y}=\mathrm{CO}_{2} \mathrm{Me} . b: \mathrm{R}=\mathrm{H}$, $\mathrm{X}=\mathrm{CO}_{2} \mathrm{Me}, \mathrm{Y}=\mathrm{CN}$. c: $\mathrm{R}=\mathrm{H}, \mathrm{X}=\mathrm{Y}=\mathrm{CN}$. $d: \mathrm{R}=\mathrm{Me}, \mathrm{X}=\mathrm{CO}_{2} \mathrm{Me}, \mathrm{Y}=\mathrm{CN} . \quad e: \mathrm{R}=\mathrm{Me}$, $\mathrm{X}=\mathrm{Y}=\mathrm{CN}$. 
work-up, whereas the same reaction of $1 c$ at low temperature monitored by ${ }^{1} \mathrm{H}$ NMR spectroscopy indicated the intermediacy of 3c. This technique also confirmed that the first step is a nucleophilic substitution of bromine by azide ion to give 2 (see Experimental).

In principle two structures (3 and 4) are possible for the primary cycloaddition product, both equally feasible as judged from molecular model considerations and both fitting the spectroscopic properties. However, based on the reported reactivity of the nitrogen atoms of the azido group, where N-1 is the more nucleophilic one and $\mathrm{N}-3$ being most electrophilic ${ }^{5}$ combined with the observed electrophilicity of the $s p^{2}$ benzylic carbon atom in $1,{ }^{1,6}$ structure 3 is considered more reason. able.

The stability of the triazolines 3 varies considerably. While $3 b$ and $3 c$ decomposed spontaneously at $(3 b)$ or well below $(3 c) 20^{\circ} \mathrm{C}$, $3 a$ was thermally stable and could be recrystallized unchanged from triethylamine, in contrast to the addition product from phenyl azide and methyl acrylate which carries an acidic hydrogen.? The thermal decomposition of $3 b$ and $3 c$ yielded quantitatively the isoindolin. ylidene derivatives $5 b$ and $5 c$ with liberation of an equimolar amount of nitrogen.

The decomposition must involve a migration (onestep or multistep) of the hydrogen atom (as proton, hydrogen atom or hydride ion) from $\mathrm{C}-9 \mathrm{~b}$ in 3 to the nitrogen atom in 5 . Thus it would be of interest to see how the introduction of a methyl group at C-9b would influence the decomposition reaction. The alkylidene derivatives $1 d$ and $1 e$ were made from $1 b$ and $1 c$ respectively, by treatment with diazomethane giving the $\Delta^{1}$-pyrazolines which in situ decomposed to $1 d$ and $1 e e^{8}$ The triazoline $3 d$ was surprisingly stable, could be recrystallized and kept for months at room temperature, while triazoline $3 e$ decomposed under the same conditions. A qualitative estimate indicated the relative thermal stabilities: $3 a>3 d>3 b>$ $3 e>3 c$.

The decomposition of $3 d$ and $3 e$ followed entirely different routes. Thus $3 e$ decomposed quantitatively at room temperature to the hitherto unknown $3 H$-isoindolenium methylide $6 e$, the structure of which was confirmed by $\mathrm{X}$-ray crystallography.' On heating above its melting point $\left(120^{\circ} \mathrm{C}\right) 3 d$ decomposed to an intractable mass (probably polymeric as judged from the ${ }^{1} \mathrm{H}$ NMR spectrum) from which no single product could be obtained. Upon addition of catalytic amounts of trifluoracetic acid $3 d$ rapidly decomposed to $6 d$.

The thermolytic decomposition of $\Delta^{2}-1,2,3$. triazolines has been studied by several groups. ${ }^{10-12}$ 4-Methoxycarbonyl-5-phenyl $-\Delta^{2}$. 1,2,3-triazoline gave quantitative yields of the corresponding 1-phenyl-2-methoxycarbonylaziridine.$^{10}$ In addition to aziridines enamines were also found as products in the decompositions of $\Delta^{2}-1,2,3$-triazoline having electronegative substituents in 4-position.11 Aziridines and cyclic imines were observed as products of the thermal decomposition of bicyclic $\Delta^{2}-1,2,3$. triazolines having alkyl substituents in $4 \cdot$ and 5-positions. ${ }^{3}$ Although no conclusive evidence concerning the mechanism of decomposition is presented, it has been assumed that the first step is cleavage of one $\mathrm{N}-\mathrm{N}$ bond. Based on kinetic measurements ${ }^{10}$ it is suggested that this bond breaking is homolytic. ${ }^{12}$

The relative stabilities of the $3 a, 3 b$ and $3 c$ and $3 d$ and $3 e$, respectively, lead us to suggest that in this system the $\mathrm{C}_{1}-\mathrm{N}_{2}$ bond is the

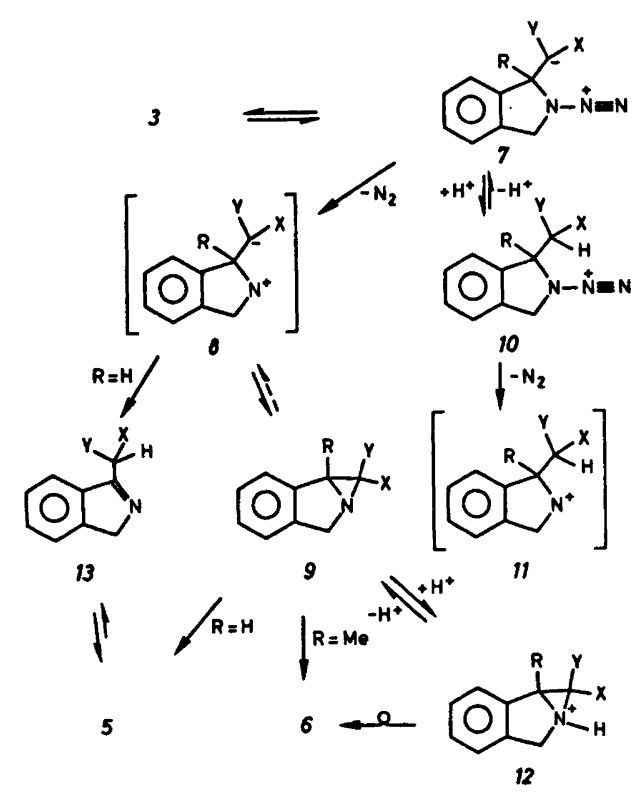

Scheme 2.

Acta Chem. Scand. B 32 (1978) No. 9 
weaker one. Cleavage of this bond gives us the zwitterion \%. The isolation of 4-substituted oxazolines from decomposition of 4-acetylsubstituted $\Delta^{2}-1,2,3$-triazoline also points to a corresponding zwitterion. ${ }^{13}$ The stability of 7 is a function of substituents $X$ and $Y$. When both are methoxycarbonyl groups the equilibrium $3 \rightleftharpoons 7$ is shifted completely to the left. When $\mathrm{X}$ and/or $\mathrm{Y}$ are cyano groups, zwitterion 7 is expected to have lower free energy as the corresponding carbon acids dissociate easier by introduction of cyano groups. (Malononitrile, $\mathrm{p} K_{\mathrm{A}}=11.7$, malonic ester $\mathrm{p} K_{\mathrm{A}}=13.5$ ).

The acid-catalyzed decomposition of $3 d$ is understandable in that protonation of 7 leads to 10 which most certainly rapidly would loose nitrogen to give 11 . That the aziridines 9 are true intermediates, at least when $R=M e$, is reasonable. We have been able, by low temperature ${ }^{1} \mathrm{H}$ NMR spectroscopic monitoring, to observe signals from an unknown intermediate in the acid-catalyzed decomposition of triazoline $3 d$. The signals appear in the vicinity of the methylene and methyl signals of $6 d$, and may possibly stem from aziridine $9 d$ (or $12 d)$.

The formation of the isoindolinylidene derivatives 5 from the nonmethylated triazolines does not necessarily involve the intermediacy of aziridines. They may simply be formed in a concerted manner directly from switterion 7 by a 1,2-shift of hydrogen. Another mechanistic possibility is that the imine 13 is formed in a concerted manner from 7 and then tautomerized to 5 .

\section{EXPERIMENTAL}

General. Spectroscopic data were recorded on a Varian A 60A NMR spectrometer, an HA 100-15D NMR spectrometer (operating at $98 \mathrm{MHz}$ ), a JEOL FX60-NMR-spectrometer, a Perkin-Elmer 457 IR spectrophotometer, a Cary 16 UV spectrophotometer and an AEI MS 902 mass spectrometer. Molecular weights were obtained using a Knauer Vapor Pressure Osmometer. Melting points are not corrected.

Materials. The o-bromomethylbenzylidene compounds $1 a, 1 b$ and $1 c$ were synthesized as described previously. ${ }^{1}$ Alkylidene derivatives $1 d$ and $1 e$ were made by mixing ether solutions of $1 b$ and $1 c$ with $5 \%$ excess of diazomethane in ether. After the nitrogen evolution had ceased the ether was evaporated leaving oils which partly crystallized. Recrystallization from methanol gave pure $1 d$ and 1e. 1d: M.p 93-95 ${ }^{\circ}$ C. Found: $\mathrm{C}$ 53.6; H 4.3; N 5.1 Calc. for $\mathrm{C}_{18} \mathrm{H}_{12} \mathrm{BrNO}_{2}$ : $\mathrm{C} 53.1$; $\mathrm{H} 4.1 ; \mathrm{N} 4.8 .{ }^{1} \mathrm{H}$ NMR $\left(98 \mathrm{MHz}, \mathrm{CDCl}_{3}\right): \delta 2.75(3 \mathrm{H}, \mathrm{s}), 3.89(3 \mathrm{H}, \mathrm{s})$, $4.46(2 \mathrm{H}, \mathrm{s}), 6.9-7.6(4 \mathrm{H}, \mathrm{m})$. 1 e: M.p. $75-77^{\circ} \mathrm{C}$. Anal. $\mathrm{C}_{12} \mathrm{H}_{9} \mathrm{BrN}_{2}: \mathrm{C}, \mathrm{H}$. ${ }^{1 \mathrm{H}} \mathrm{NMR}(98 \mathrm{MHz}$, $\left.\mathrm{CDCl}_{3}\right): 2.65$ (3 H, s), $4.42(2 \mathrm{H}, \mathrm{s}), 6.9-7.3$ (1 $\mathrm{H}, \mathrm{m}), 7.3-7.6(3 \mathrm{H}, \mathrm{m})$.

(3a). $1 a$ (15.7 g $0.05 \mathrm{~mol})$ was dissolved in $250 \mathrm{ml}$ of methanol and sodium azide $(3.25 \mathrm{~g}$, $0.05 \mathrm{~mol}$ ) dissolved in $100 \mathrm{ml}$ of water was added dropwise (room temperature) while nitrogen was bubbled through the solution. After $2 \mathrm{~h}$ the greyish precipitate was collected, $10.8 \mathrm{~g}(78 \%)$, m.p. $95-96^{\circ} \mathrm{C}$ (MeOH). Anal. $\mathrm{C}_{13} \mathrm{H}_{13} \mathrm{~N}_{3} \mathrm{O}_{4}$ : C, $\mathrm{H}, \mathrm{N}$. Mol. wt., calc. 275, found 274. MS: $247\left(\mathrm{M}^{+}-\mathrm{N}_{2}\right)$. IR $(\mathrm{KBr})$ : 1735 (s) $\mathrm{cm}^{-1}$. ${ }^{1} \mathrm{H}$ NMR $\left(60 \mathrm{MHz}, \mathrm{CDCl}_{3}\right)$ : $\delta 3.70(3 \mathrm{H}, \mathrm{s}), 3.92(3 \mathrm{H}, \mathrm{s}), 4.68(1 \mathrm{H}, \mathrm{d}$, $J 15.5 \mathrm{~Hz}), 5.34(1 \mathrm{H}, \mathrm{d}, J 15.5 \mathrm{~Hz}), 5.71$ (1 H, s) $7.0-7.4(4 \mathrm{H}, \mathrm{m}) .{ }^{18} \mathrm{C}$ NMR (15 MHz, $\left.\mathrm{CDCl}_{3}\right): \delta 53.0$ and $54.0\left(2 \times \mathrm{CH}_{3} \mathrm{O}\right), 55.0$ (C5), 68.2 (C9b) 95.0 (Cl), $123.2-127.9-129.3$ (C6-C9), 136.0 and $137.6(\mathrm{C} 5 a+\mathrm{C} 9 \mathrm{a}), 165.0$ and $165.3(\mathrm{C}=\mathrm{O})$.

$(5 b) .1 b(10.2 \mathrm{~g}, 0.035 \mathrm{~mol})$ was dissolved in $350 \mathrm{ml}$ of methanol kept at $40-50^{\circ} \mathrm{C}$. An aqueous solution $(0.8 \mathrm{M})$ of sodium azide $(2.4 \mathrm{~g}, 0.035 \mathrm{~mol})$ was added dropwise while nitrogen was bubbled through the solution. After cooling for $24 \mathrm{~h}$ the precipitate was collected, $4.0 \mathrm{~g}(52 \%)$, m.p. $236^{\circ} \mathrm{C}(\mathrm{MeOH})$. Anal. $\mathrm{C}_{12} \mathrm{H}_{10} \mathrm{~N}_{2} \mathrm{O}_{2}: \mathrm{C}, \mathrm{H}, \mathrm{N}$. MS: [IP $70 \mathrm{eV}$; $m / e$ (\% rel.int.) $] 214(100, \mathrm{M}), 199\left(20, \mathrm{M}-\mathrm{CH}_{3}\right)$, $183\left(30, \mathrm{M}-\mathrm{OCH}_{3}\right), \quad 181\left(28, \mathrm{M}-\mathrm{CH}_{3}-\mathrm{H}_{2} \mathrm{O}\right)$; $m^{*} 199-181$, obs. 164.7 , calc. 164.6. ${ }^{1}$ NMR (60 $\left.\mathrm{MHz}, \mathrm{CF}_{3} \mathrm{COOH}\right): \delta 3.92(3 \mathrm{H}, \mathrm{s}), 4.77$ (2 H, s) 7.5-7.8 (3 H, broad), 8.2-8.6 (1 H, broad). ${ }^{13} \mathrm{C}$ NMR (15 MHz, DMSO- $d_{6}$ ): $\delta 50.5$ $\left(\mathrm{OCH}_{3}\right), 51.8$ (C3), 63.1 (C8), $118.1(\mathrm{C} \equiv \mathrm{N})$, $122.8-124.0-127.4-131.3$ (C4-C7) 132.2$143.3(\mathrm{C} 3 a+\mathrm{C} 7 a), 163.9-167.4(\mathrm{C}=\mathrm{O}$ and $\mathrm{Cl})$. IR (KBr): 3330 (s), 2210 (s), 1670 (s), 1605 (s) $\mathrm{cm}^{-1}$.

1-Cyano-1-methoxycarbonylisoindolino[2,1-c]$\Delta^{2}$-triazoline $(3 b) .16(5.6 \mathrm{~g}, 0.02 \mathrm{~mol})$ was dissolved in $35 \mathrm{ml}$ methylene chloride and cooled to $-10^{\circ} \mathrm{C}$. While stirring the solution tetrabutylammonium azide $(6.0 \mathrm{~g}, 0.021 \mathrm{~mol})$ dissolved in $35 \mathrm{ml}$ methylene chloride was added dropwise. After 30 min ${ }^{1} \mathrm{H}$ NMR showed the absence of peaks from the starting material and $100 \mathrm{ml}$ icewater was added, stirring was continued for $15 \mathrm{~min}$ at $0^{\circ} \mathrm{C}$. The phases were separated and the lower organic phase was twice washed with icewater. After drying $\left(\mathrm{MgSO}_{4}\right)$ the solvent was evaporated at $0^{\circ} \mathrm{C}$. The residue $(6 \mathrm{~g})$ was dissolved in chloroform and pentane added. After cooling $\left(-35^{\circ} \mathrm{C}\right)$ the triazoline precipitated as off-white crystals. Leaving these crystals at room temperature for a prolonged time $(15-20 \mathrm{~min}$.) resulted in decomposition (see below). ${ }^{1} \mathrm{H}$ NMR (98 $\mathrm{MHz}, \mathrm{CDCl}_{3}$ $-40^{\circ} \mathrm{C}: \delta 3.98(3 \mathrm{H}, \mathrm{s}), 4.75(1 \mathrm{H}, \mathrm{d}, J 16.0 \mathrm{~Hz})$, 5.08 (1 H, s), 5.35 (1 H, d, J $15.5 \mathrm{~Hz}), 7.2-7.6$

Acta Chem. Scand. B 32 (1978) No. 9 
$(4 \mathrm{H}, \mathrm{m}) .{ }^{13} \mathrm{C}$ NMR $\left(15 \mathrm{MHz}, \mathrm{CHCl}_{3},-35^{\circ} \mathrm{C}\right)$ : $\delta 55.2$ (C5), $55.4 \quad\left(\mathrm{OCH}_{3}\right), 68.8$ (C9b), 84.1 (C1), $111.9(\mathrm{C} \equiv \mathrm{N}), 123.1-124.6-128.4-130.0$ (C6-C9), 134.2 and $136.6(\mathrm{C} 5 \mathrm{a}+\mathrm{C} 9 \mathrm{a}), 163.0$ $(\mathrm{C}=0)$.

Decomposition of triazoline (3b). $3 b(484 \mathrm{mg}$, $2 \mathrm{mmol}$ ) was dissolved in chloroform kept at $50^{\circ} \mathrm{C}$. Rapid nitrogen evolution occurred. Found $47.4 \mathrm{ml} \mathrm{N}_{2}$, calc. $49.2 \mathrm{ml}(T=300 \mathrm{~K})$. Evaporation of the solvent gave a quantitative yield of $5 b$.

(5c). $1 c(4.9 \mathrm{~g}, 0.02 \mathrm{~mol})$ was dissolved in $100 \mathrm{ml}$ methanol kept at $40-50^{\circ} \mathrm{C}$. An aqueous solution $(1 \mathrm{M})$ of sodium azide $(1.3 \mathrm{~g}, 0.02 \mathrm{~mol})$ was added dropwise (under nitrogen). After cooling for $24 \mathrm{~h}$ a precipitate was collected, $1.5 \mathrm{~g}, \mathrm{~m} . \mathrm{p} .>250^{\circ} \mathrm{C}(\mathrm{MeOH})$. Anal. $\mathrm{C}_{11} \mathrm{H}_{7} \mathrm{~N}_{3}$ ): C, H. MS [IP 70 eV; $m / e(\%$ rel.int)] 181 $(100, M), 180$ (82, M-1). ${ }^{13} \mathrm{C}$ NMR (15 MHz, DMSO-d $\left.d_{6}\right): 51.9$ (C3), $115.5-116.0 \quad(\mathrm{C} \equiv \mathrm{N})$, 122.9-123.5-127.6-131.7 (C4-C7), 131.2143.6 (C3a; C7a), 165.9 (C1). IR (KBr): 3270 (s), 2218 (s), 2210 (s), 1623 (s), 1610 (s), 1580 (s) $\mathrm{cm}^{-1}$.

Reaction between bromide Ic and tetrabutylammonium azide. Equimolar quantities of 1c and tetrabutylammonium azide in deuteriochloroform were mixed at $-60^{\circ} \mathrm{C}$ and the reaction was monitored by ${ }^{1} \mathrm{H}$ NMR (HA $100-15 \mathrm{D})$. At $-60^{\circ} \mathrm{C}$ a peak gradually appeared in the olefinic region at $8.32 \mathrm{ppm}$ (1c: 8.43) and another at $4.51 \mathrm{ppm}$ (1c: 4.61$)$. This corresponds to substitution of the bromide ion by the azido group $\left(1 c \stackrel{\mathrm{N}_{8}^{-}}{\longrightarrow} 2 c\right)$. At $-40^{\circ} \mathrm{C}$ the only change was an increase of the intensity of the peaks at 8.32 and $4.51 \mathrm{ppm}$. At $-15^{\circ} \mathrm{C}$ these peaks decreased in intensity while peaks at $4.69,4.86,5.33,5.49$ (AB-pattern of geminal methylene protons at $\mathrm{C5}$ in $3 c$ ) and $5.51 \mathrm{ppm}$ (methin proton at $\mathrm{C} 9 \mathrm{~b}$ in $3 c$ ) increased. At even higher temperature gas was evolved and $5 c$ started to precipitate.

1.Cyano-1-methoxycarbonyl-9b-methylisoindolino[2,1-c] $4^{2}$-triazoline $(3 d)$. $1 d(5.88 \mathrm{~g},(0.02$ mol) was dissolved in $35 \mathrm{ml}$ methylene chloride. Tetrabutylammonium azide $(6.0 \mathrm{~g}, 0.021 \mathrm{~mol})$ dissolved in $35 \mathrm{ml}$ methylene chloride was added slowly to the above solution (while stirring). After 30 min all starting material had reacted (checked by ${ }^{1} \mathrm{H}$ NMR) and tetrabutylammonium bromide was removed by repetitive extraction with water. Evaporation of the organic solvent gave $3 d, 4.0 \mathrm{~g}(78 \%)$, m.p. $120^{\circ} \mathrm{C}$ (dec.-MeOH). Anal. $\mathrm{C}_{13} \mathrm{H}_{12} \mathrm{~N}_{4} \mathrm{O}_{2}$ : C, H, N. MS: $228\left(M^{+}-\mathrm{N}_{2}\right) .{ }^{1} \mathrm{H}$. NMR $(60 \mathrm{MHz}$, $\left.\mathrm{CDCl}_{3}\right): \delta 1.92(3 \mathrm{H}, \mathrm{s}), 3.72(3 \mathrm{H}, \mathrm{s}), 4.66$ $(1 \mathrm{H}, \mathrm{d}, J=16 \mathrm{~Hz}), 5.28(1 \mathrm{H}, \mathrm{d}, J=16 \mathrm{~Hz})$, 6.9-7.5 (m, 4 H). ${ }^{18} \mathrm{C}$ NMR (15 $\left.\mathrm{MHz} \mathrm{CDCl}_{3}\right)$ : $\delta 24.7\left(\mathrm{CH}_{3}-\mathrm{C}\right), 53.7(\mathrm{C} 5), 53.9\left(\mathrm{CH}_{3} \mathrm{O}\right), 76.6$ (C9b), 86.2 (Cl), 112.4 (C $\equiv \mathrm{N}), 122.3-123.5-$ $28.4-129.8$ (C6-C9), $135.9-139.8$ (C5a + C9a), $162.6(\mathrm{C}=\mathrm{O})$.

1,1-Dicyano-9b-methylisoindolino[2,1-c] $\Delta^{2}$-triazoline (3e). Following the same procedure as for preparation of triazoline $3 b, 3 e$ was obtained. Left at room temperature for some time $(\sim 30$ min) the triazoline decomposed (see below). ${ }^{1} \mathrm{H}$ NMR (98 $\left.\mathrm{MHz}, \mathrm{CDCl}_{3},-40^{\circ} \mathrm{C}\right): \delta 1.93$ $(3 \mathrm{H}, \mathrm{s}), 4.71$ (1 H, d, $J=16 \mathrm{~Hz}), 5.37$ (1 H, d, $J=16 \mathrm{~Hz}), 7.2-7.8(4 \mathrm{H}, \mathrm{m}) .{ }^{13} \mathrm{C}$ NMR $(15 \mathrm{MHz}$, $\left.\mathrm{CDCl}_{3},-40^{\circ} \mathrm{C}\right): \delta 23.0\left(\mathrm{CH}_{3}-\mathrm{C}\right), 53.8(\mathrm{C} 5)$, 74.3 (C9b), $81.5(\mathrm{Cl}), 109.0-109.2(2 \times \mathrm{C} \equiv \mathrm{N})$, $123.1-123.8-128.6-130.4$ (C6-C9), 134.7137.9 (C5a-C9a).

$3 \mathrm{H}$-Isoindolenium methylide $(6 d)$. Upon addition of catalytic amounts of trifluoroacetic acid to a deuteriochloroform solution of $3 d$ in the NMR tube $6 d$ was formed. ${ }^{1} \mathrm{H}$ NMR (98 $\mathrm{MHz}$, $\left.\mathrm{CDCl}_{3}\right): \delta 3.00(\mathrm{t}, 3 \mathrm{H}, J=2 \mathrm{~Hz}), 3.90(\mathrm{~s}, 3 \mathrm{H})$, 5.20 (q, $2 \mathrm{H}, J=2 \mathrm{~Hz}), 7.5-8.2(\mathrm{~m}, 4 \mathrm{H})$. ${ }^{13} \mathrm{C}$ NMR (15 $\left.\mathrm{MHz}, \mathrm{CDCl}_{3}\right) \delta 15.7\left(\mathrm{CH}_{3}-\mathrm{C}\right)$, $56.3\left(\mathrm{CH}_{3} \mathrm{O}\right), \quad 58.8$ (C3), 109.0 (C8), 118.7 $(\mathrm{C} \equiv \mathrm{N}), \quad 125.5-128.1-132.2-139.0 \quad$ (C4-C7), $134.9-147.8 \quad(\mathrm{C} 3 \mathrm{a}-\mathrm{C} 7 \mathrm{a}), \quad 166.8 \quad(\mathrm{C}=\mathrm{O})$, 186.5 (Cl).

$3 \mathrm{H}$-Isoindolenium methylide $(6 e)$. $3 \mathrm{e}$ decomposed in the NMR-tube when the probe temperature was raised to $30^{\circ} \mathrm{C}$. Anal. $\mathrm{C}_{12} \mathrm{H}_{8} \mathrm{~N}_{3}$ : C, H. ${ }^{1} \mathrm{H}$ NMR $\left(60 \mathrm{MHz}, \mathrm{CDCl}_{3}\right) \delta 2.78(3 \mathrm{H}, \mathrm{t}$, $J=2 \mathrm{~Hz}), 5.26(2 \mathrm{H}, \mathrm{q}, J=2 \mathrm{~Hz}), 7.52(4 \mathrm{H}, \mathrm{s})$. ${ }^{13} \mathrm{C}$ NMR (15 $\left.\mathrm{MHz}, \mathrm{CDCl}_{3}\right): \delta 16.6\left(\mathrm{CH}_{3}-\mathrm{C}\right)$, 63.9 (C3), $99.0(\mathrm{C} 8), 119.0(2 \times \mathrm{C} \equiv \mathrm{N}), 121.1$ $-122.1-129.6-131.3$ (C4-C7), 136.7-137.6 $(\mathrm{C} 3 \mathrm{a}+\mathrm{C} 7 \mathrm{a}), 175.0$ (C1). IR (KBr): 2135 (s), 2170 (s).

Acknowledgement. One of the authors (P.K.) is grateful for a grant from "Norges Almenvitenskapelige Forskningsråd."

\section{REFERENCES}

1. Kolsaker, P. and Ellingsen, P. O. Acta Chem. Scand. To be published.

2. Padwa, A. Angew. Chem. 88 (1976) 131.

3. Logothetis, A. L. J. Am. Chem. Soc. 87 (1965) 749.

4. Fusco, R., Garanti, L. and Zecchi, G. J. Org. Chem. 40 (1975) 1906.

5. L'Abbé, G. Ind. Chim. Belge 34 (1969) 519; Chem. Abstr. 71 (1969) 69819 g.

6. Kolsaker, P. and Storesund, H. J. Chem. Commun. (1972), 375.

7. Huisgen, R., Szeimies, G. and Møbius, L. Chem. Ber. 99 (1966) 475.

8. Popp, F. D. and Catala, A. J. Org. Chem. 26 (1961) 2738.

9. Rømming, C. and Kolsaker, P. Acta Chem. Scand. $B 32$ (1978) 679.

10. Szeimies, G. and Huisgen, R. Chem. Ber. 99 (1966) 491.

11. Broeck, W., Overbergh, N., Samyn, D., Smets, G. and L'Abbé, G. Tetrahedron 27 (1971) 3527.

12. L'Abbé, G. Chem. Rev. 69 (1969) 345.

13. Texier, F. and Carrier, R. C.R. Acad. Sci. Ser. $C 271(1970) 958$.

Received June 26, 1978. 